\title{
Awareness on Prohibited Elements in Muamalat: Common Practice in Life
}

\author{
Wan Musyirah Wan Ismail ${ }^{1 *}$, Ida Rahayu Mahat², Nurul Asma Mazlan \\ ${ }^{1}$ Faculty of Business Management, Universiti Teknologi MARA Cawangan \\ Melaka, Kampus Bandaraya Melaka, 75300, Malaysia \\ ${ }^{2}$ Academy of Language Studies, Universiti Teknologi MARA Cawangan Melaka, \\ Kampus Jasin, 77300, Malaysia \\ ${ }^{3}$ Faculty of Law Studies, Universiti Teknologi MARA Cawangan Melaka, \\ Kampus Alor Gajah, 78000, Malaysia \\ ${ }^{*}$ Corresponding Author \\ musyirah792@uitm.edu.my
}

Received: 11 June 2020

Accepted: 30 June 2020

Online First:

\begin{abstract}
Muamalat in Islam literally means transaction and technically means any mutual dealing that exist between two parties in order to solve their everyday needs, normally in trade and commerce. In Islamic economy, it is based on figh al-muamalat, which regulates the trading and commercial activities. There are three prohibited elements in transaction namely riba (interest), gharar (uncertainty), and maysir (gambling). However, certain Muslim community are still practising the trading that consist of these elements. An existence of many Islamic banks in Malaysia since 1983, however, seems unable to eliminate these elements in the Muslim's daily life. Therefore, this paper aims to examine the awareness of the public regarding the practice of these three prohibited elements in their daily life. This study used quantitative method and employed descriptive studies. 150 questionnaires were distributed to the public using simple random sampling. Results found that there are lack of awareness of respondents regarding common activities in our daily life that contains prohibited elements. It is
\end{abstract}


Journal of Contemporary Islamic Studies

recommended to give more knowledge regarding prohibited elements to the Muslims through social media.

Keywords: Muamalat, Transaction, Riba, Gharar, Maysir

\section{INTRODUCTION}

Muamalat is Arabic word which means dealings. Literally, it means transactio $\mathrm{n}$, while technically it means any form of mutual dealings held between people to do a transaction for their needs, such as in trading and commerce. Basically, muamalat is seen as economy activities. However, muamalat is a social relationship which consist of various economic and non-economic activities (Saifudin, 2017). In addition, an elements of muamalat or the factor that bind the activities called as muamalat are when the activity creates a responsibility among people, the activity comes from mutual agreement, and last but not least, the activity has formality which bind the activity such as by offer and acceptance by two parties.

Islamic economy is driven by fiqh muamalat. Fiqh muamalat is an Islamic regulation that relate to trading and commercial rules. Based on encyclopedia, Fiqh Muamalat defined as a branch of Islamic jurisprudence that cover the area of commercial and business activities in economy. Originally, Fiqh understanding of rulings, and mumalat refer to the transaction and activities related to the economy such as in Islamic banking offer bai' ijarah, ijarah, murabahah and mudharabah. Fiqh Muamalat deals with the rulings which define and govern the relationship between humans, for example in term of financial right and obligation among them. (Encylopedia, 2013)

Muamalat means transaction. According to islam, any transaction occur must be in line with Syariah. It is because, Islam regulate certain criteria that will make the transaction becomes haram. First, the transaction or contract bound should not be made for selling or buying forbidden products. Forbidden products in Islam such as alcohol and pork. Second, the contract occur must be not included any interest (riba'). Riba is addition from the principal amount. The lender asks for extra amount from the principal for borrower to pay. Third, the contract involves uncertainty 
(gharar) is prohibited. Gharar is any transaction of probable objects whose existence or description are not certain, it may because of information and knowledge of the ultimate outcome of the contract or the nature and quality of the subject matter of it. Fourth, the transaction that involves gambling (maysir) is strictly prohibited in Islam. Maysir means any gains derived based on opportunity or luck. It also can be defined as easy acquisition of wealth by chance, and also any business activity where monetary gains are deriving from mere chance and speculation. Prohibition of Riba, Gharar and Maysir in financial transactions is the fundamental of Islamic finance which distinguishes it from conventional finance. Therefore, it is a must for Muslims to avoid these elements from exist in their daily transaction (Uddin, 2015).

\section{Problem Statement}

In daily life, many transactions occur as well as economy and noneconomy activities. For example, buying and selling is one of common activity that people do every day. As a Muslim, every transaction must be done in line with shariah. In muamalat or transaction, there are a few prohibitions that Muslim must be avoid. Islam underlying three prohibited elements which is strictly prohibited or haram to apply in any transaction or trading. These three elements were clearly stated in the Holy Quran regarding its prohibition. The prohibition of interest (riba), uncertainty (gharar) and gambling (maysir) that Muslims need to ensure to avoid from implement in any transaction they do. According to Saifudin (2017), all economic activities are legally permissible, as long as they do not commit with any prohibition stated in Islamic law or Shariah. It is in line with all four scholars which are Hanafi, Maliki, Shafi'e and Hanbali that all forms of transaction or business that include in any of these prohibited elements considered as invalid transaction.

There are a lot of verses in the Holy Quran regarding the prohibition of riba, gharar and maysir. Among the verses of prohibition of riba' are:

" and Allah permitted trade and prohibited riba", (The Quran 2: 275), and

"O you who have believed, do not consume usury, doubled and multiplied, but fear Allah that you may be successful" (The

Quran 3: 130) 
Prohibition of uncertainty (gharar) also stated in the Holy Quran.

"And do not consume one another's wealth unjustly or send it [in bribery] to the rulers in order that [they might aid] you [to] consume a portion of the wealth of the people in sin, while you know [it is unlawful]." (The Quran 2:188), and "O you who have believed, do not consume one another's wealth unjustly but only [in lawful] business by mutual consent. And do not kill yourselves [or one another]. Indeed, Allah is to you ever Merciful." (The Quran 4: 29)

While verses for prohibition of Maysir (gambling) stated in The Quran:

"O you who have believed, indeed, intoxicants, gambling, [sacrificing on] stone alters [to other than Allah], and divining arrows are but defilement from the work of Satan, so avoid it that you may be successful." (The Quran 5: 90), and

"They ask you about wine and gambling. Say, "In them is great sin and [yet, some] benefit for people. But their sin is greater than their benefit." And they ask you what they should spend. Say, "The excess [beyond needs]." Thus, Allah makes clear to you the verses [of revelation] that you might give thought." (The Quran 2:219)

Islam strictly prohibited these three elements in any transaction occur. However, in common practices, these elements are still existing in transaction either directly or indirectly. This paper aims highlighted the common transactions or practice that could occur in our daily life consist of these three elements. The common practice highlighted is not limited to financial activities, however it is also focus on day to day activities that Muslim did not realize it is lead to haram transaction. Therefore, it is crucial to investigate an awareness of Muslims towards prohibited elements in Muamalat in order to know the level of knowledge among Muslims regarding this issue. 


\section{LITERATURE REVIEW}

\section{Riba (Interest) in Common Practice}

A root word of riba' is ribh. It means increase in or addition to. Riba can be define as additional amount to the original amount, or an excess to the principal amount, which the extra is charge by the lender to the borrower of money. It means for example, the buyer lends for Rm 1000 but the lender ask to pay for RM 1500. It was existing since in pre Islamic period in money lending and barter system activities. During that period, it is like a common practice as it lead to the rich become richer and poor become poorer. It is because the poor will borrow the money form the rich to buy something for their needs. However, they need to pay extra amount compared to the amount they borrow. Thus, it will make hardship to the poor to pay their loan (Mohammed, 2013).

In addition, during that period, because of the hardship then the borrower asks to extend the period for payment. As the period extend, the amount of payment also increases. It was really burdening the borrower and because of this, many verses in the Holy Quran reveals to prohibit riba' from implement in daily life. Allah was stated the sins of committing riba is not restricted to the who give the riba, but all people either directly or indirectly committing with riba also involved. It is as in the hadith narrated that Jaabir said:

"The Messenger of Allah (blessings and peace of Allah be upon him) cursed the one who consumes riba and the one who pays it, the one who writes it down and the two who witness it, and he said: they are all the same." Muslim (1598)

Allah prohibited riba and mention the punishment of riba' as in The Quran:

Those who consume interest cannot stand [on the Day of Resurrection] except as one stands who is being beaten by Satan into insanity. That is because they say, "Trade is [just] like interest." But Allah has permitted trade and has forbidden interest. So, whoever has received an admonition from his Lord 
and desists may have what is past, and his affair rests with Allah. But whoever returns to [dealing in interest or usury] - those are the companions of the Fire; they will abide eternally therein. (The Quran 2:275)

Nowadays, many Islamic banks exist in order to provide Islamic products and services to the Muslims. Generally, Muslims aware on existing of Islamic products to eliminate the consuming of conventional products. Therefore, for those who want to avoid from taking any prohibited element would go for transaction and trading offered by Islamic institution such as Islamic bank. It is because, chosen Islamic institution is the best solution to confirm it is free from any prohibited elements. However, there are certain transaction in our daily life that could be as a normal practice by citizen without they realize, it also contains prohibited elements.

It is common for citizen who practice multi level marketing or called as MLM. It is similar to pyramid marketing. MLM is haram because the purpose of MLM is to earn commission not to buy the product. The person at upper level will get commission from below line of level. It is like to get profit without doing nothing and not selling a product. According to Shaykh Muhammad, 2004, the commission may reach tens of thousands, while the product is not worth more than a few hundred. The companies depend on marketing and advertising of their product that will contribute to a large profit to their companies. Besides, the prohibition of MLM is because of it contains riba al-fadhl as well as riba nasiah. Riba al-fadhl is when exchange of good with the same type but different quantity and riba nasiah is regarding the time of payment where when the payment makes later, the amount of payment will increase. In case of MLM, the participant pays a small amount of money in order to gain a lot of money or can be conclude that they pay cash for cash of a different amount and with deferred payment. In addition, the product which the company sells to the agent is actually a screen for this transaction, which intend to trick others, however, it makes no difference to the ruling.

Insurance also is a common practice by citizen. Insurance is haram because of a few factors and one of it because of riba. Insurance clearly contains riba. Insurance is the sale of money for money, of a greater or lesser amount, with delay in one payment. In case of insurance, it contains riba 
al-fadhl and riba al-nasiah. Riba al-fadhl is when the amount of money is not equal, thus it contains interest, and riba al-nasiah is based on time. These both riba incurred because in insurance, company take people's money and promise to pay them either an amount is more or less than the amount they had pay and the payment will be made because of specific accident happen and stated in the policy. Thus, the amount of money they pay is not equal to the amount they receive, and the amount paid is in the future, thus this will make riba existed and riba is strictly prohibited.

\section{Gharar (Uncertainty) in Common Practice}

Gharar commonly known as uncertainty. Gharar literally means peril, hazard, undisclosed and uncertainty. Gharar can be describe as to take the plunge yourself from an act which carries the risk which do not know what exactly could be happen. It also like enter into something risky without thinking the consequences, or consequences are hidden or ignorance during the transaction or sale. In sales activities, uncertainty or gharar could happen when there is uncertainty in the quality, or quantity in the subject matter, time of payment of deferred sales, value of subject matter, uncertainty of existence of subject matter, ownership, deliverability and uncertainty of nature of the object. All these unknown specifically regarding the subject matter could lead to the existence of gharar. (Muhammad Iman, 2016)

According to Muhammad Iman (2016), it has some reasons why gharar is strictly prohibited in Islam. One of it is to avoid fraudulence. It is purposely to secure the buyer especially in sales activities. It can be avoid from selling non existence product, avoid from misleading the price, and ensure that both parties agree with the contract. Besides that, this will keep the property among the people as one element in the maqasid shariah. It will help to protect the wealth and goods from the loss and teach both contracting parties to be honest and disclosed everything regarding the subject matter.

There is a few verses in the Holy Quran regarding the prohibition of gharar. One of it is in The Quran 2:188;

"And do not consume one another's wealth unjustly or send it [in bribery] to the rulers in order that [they might aid] you [to] consume a portion of the wealth of the people in sin, while you know [it is unlawful]." (The Quran 2:188) 
Journal of Contemporary Islamic Studies

And also stated in the hadith, for example in hadith Narrated by Abu Hurairah:

"The Prophet SAW has prevented (us) from (doing) a sale (by means of a small stone throw) and sale of goods in a gharar" (HR Muslim)

Gharar is uncertainty where people do not know an exact detail on transaction occur. This is not limited to the banking and financial transaction only. It is because, in our daily life activities could also exist this prohibited element in Islam. An example for the common practice of activities involver gharar is clinic or hospital bill and consultation. According to Dr Zaharuddin Abd Rahman, 2017, when the patient get the treatment in the clinic or hospital, all the information regarding the price and details of services and medicine need to be disclosed clearly at the beginning of the contract. If it is not doing so, it will lead to gharar fahish. It is important to give information on the consultation fees or treatment fees before it would be done. It must be clearly stated for example RM20 per 10 minutes consultation. The clinic or hospital cannot just assume that patient already know. Therefore, it is a must for the clinic or hospital to disclose the charges including medicine price.

Another example is gharar existed in restaurant. It is happened when owner of the restaurant did not disclose the price of the food. Therefore, when the customer orders the food, then they eat without knowing the price of the food. It will result when they want to make a payment, sometimes they will surprise with the food price. It may be too expensive. This is involved gharar fahish in the transaction. Therefore, it is important for the owner to disclose all the price to avoid gharar. In Islam, elimination of gharar is important to protect both side from mistreated (Zaharuddin, 2017).

\section{Maysir (Gambling) in Common Practice}

Maysir is known as gambling. Literally it means gambling. It is defining as easy acquisition of getting something by chance towards money, wealth or product. Maysir also defined as any form of business activity where monetary gains are derived from mere chance, speculation or conjecture. In case of gambling, all parties involve will put something usually money, however only one party will get profit and the other will lose. Common 
example of gambling is uncertainty of the timing of benefits of a pure life insurance and Casinos where it simply transfers of wealth take place from losers to winner without creating a new stock of wealth.

Maysir is prohibited in Islam because it is speculative of something either it could be profit or loss. it is more to analysis of a lot of economic and financial data, and involves the investment of assets, skills and labour. Besides, maysir is effortless which people just need to speculate and depend upon to the luck. In Islam, money should be earned by work it and put on effort which able to achieve by knowledge and skill. (Saiful Azhar, 2005)

The prohibition of maysir also stated in The Quran 5: 91;

"Satan only wants to cause between you animosity and hatred through intoxicants and gambling and to avert you from the remembrance of Allah and from prayer. So, will you not desist?" (The Quran 5:91)

In the hadith, Narrated by Abu Hurairah:

The prophet peace be upon him said, "you should not bet an amount of money except on races of camels, arrows or horses"

This hadith shows that betting is something that we need to avoid. Betting is similar as gabling because one part will win, and the others will lose. It is incurred possibilities or chance of loss.

Lucky draw is one of the activities that is very common but may involve gambling. As a common activity, it looks like it is common, and nothing is wrong in doing this. However, it is actually prohibited because the way of applying this activity included prohibited element. Lucky draw is the fortune of the draw which means the consequences of opportunity and it is based on luck. It is like a competition where the ticket will be chosen, and only selected people based on the ticket chosen will get the reward. Therefore, it is an opportunity where all people have the same opportunity but only selected will get the reward. According to Dr Hanudin Amin (2018) lucky draw is a game of chance in which people may give a money for small amount but will get back for a higher amount. There is not restricted 
to money only, but it could be in terms of prize or things. In Islam, lucky draw is strictly prohibited. It is because, lucky draw put an individual without any control towards an outcome. It is based on luck, therefore in this case, it is very high degree of gharar. Besides that, people put a little amount of money and managed to get huge amount. This is a concept of maysir. This is common practice of lucky draw where the present of lucky draw is bought by part of participant's money. However, if the present is buy by organizer's money, without involved any money by participant, then it is allowed and halal.

Another common practice that including gambling is contest. When entering contest, usually we need to pay fee. Therefore, if part of the fee is purposely to buy the prize, then it will consider as gambling. It is because, the concept of gambling is there. All participants pay equally for certain amount, then some of them will get prize with certain amount. It can be summarizing that, some of them will get profit on it by getting prize, and some of them loss of their money paid earlier. According to Saiful Azhar, 2005 , people are willing to risk their money in the hope of winning a larger amount. This is very common practice in Malaysia and sometimes has a wide scale promotion by media. It is for example SMS contest, puzzle contest, and game show contest.

\section{METHODOLOGY}

This research is conducted with the intention to get the feedback and response from the Muslims to know the level of awareness among the Muslims toward prohibited elements in Muamalat. This research used quantitative method, which used descriptive studies. 150 questionnaires were distributed to the public using simple random sampling. This involves respondents with various demographic background to get different views from them.

The questionnaire distributed randomly to Klang Valley area regardless students or workers, men or women, and any level of age. The result will analyse in order to know the level of awareness among Muslims towards prohibited elements in Muamalat. 


\section{FINDINGS}

Prohibited elements in banking and finance which are riba, gharar and maysir commonly known by the Muslims. However, majority of us do not realize that all these elements could involve in our daily life activities. Muamalat covered economic and non-economic activities. Thus, prohibited elements in Muamalat may occur without the Muslims realized it. It is because some of the activities were become a custom or tradition from past years ago.

Among the common practice by Muslims which they unrealized it contains riba are activities of Multi level Marketing (MLM) and insurance. MLM contains riba al-fadh and riba al-nasiah (Shaykh Muhammad, 2004). Riba al-fadhl is when exchange of good with the same type but different quantity and riba nasiah is regarding the time of payment where when the payment makes later, the amount of payment will increase The concept of MLM lead to haram is because the purpose of MLM is to earn commission not to buy the product. The person at upper level will get commission from below line of level. It is like to get profit without doing nothing and not selling a product. It same goes to insurance whereby many Muslim buy Insurance. Insurance is the sale of money for money, of a greater or lesser amount, with delay in one payment. Insurance also contains both riba alfadhl and riba al-nasiah. Riba al-fadhl is when the amount of money is not equal, thus it contains interest, and riba al-nasiah is based on time. These both riba incurred because in insurance, company take people's money and promise to pay them either an amount is more or less than the amount they had pay and the payment will be made because of specific accident happen and stated in the policy. Thus, the amount of money they pay is not equal to the amount they receive, and the amount paid is in the future, thus this will make riba existed and riba is strictly prohibited (Shakyh Muhammad, 2004).

Activities that is commonly practice that contains gharar are transaction in clinic or hospital for their bill and consultation. According to Dr Zaharuddin Abd Rahman (2017), when the patient gets the treatment in the clinic or hospital, all the information regarding the price and details of services and medicine need to be disclosed clearly at the beginning of the contract. If it is not doing so, it will lead to gharar fahish. Next is gharar which could happen in restaurant. It is happened when owner of the restaurant did not disclose the price of the food. Therefore, when the 
customer orders the food, then they eat without knowing the price of the food. It will result when they want to make a payment, sometimes they will surprise with the food price. It may be too expensive. This is involved gharar fahish in the transaction (Zaharuddin, 2017).

For activities that contains maysir, and it is common practice in our life for example lucky draw (Hanudin, 2018) and contest (Saiful Azhar, 2005). Lucky draw is a game of chance in which people may give a money for small amount but will get back for a higher amount. There is not restricted to money only, but it could be in terms of prize or things. In Islam, lucky draw is strictly prohibited. It is because, lucky draw put an individual without any control towards an outcome. It is based on luck, therefore in this case, it is very high degree of gharar. Besides that, people put a little amount of money and managed to get huge amount. This is a concept of maysir. This is applied if the participants contribute money for the prize. Contest also similar like gambling. It is because entering into contest, usually we need to pay fee. Therefore, if part of the fee is purposely to buy the prize, then it will consider as gambling. In this case, all participants pay equally for certain amount, then some of them will get prize with certain amount. It can be summarized that, some of them will get profit on it by getting prize, and some of them loss of their money paid earlier. This is very common practice in Malaysia such as SMS contest, puzzle contest, and game show contest.

These activities were highlighted in the questionnaire to let the respondents know regarding its prohibited. An awareness of its prohibition was evaluated. The findings identified;

\begin{tabular}{|c|l|c|}
\hline No & Statement & $\begin{array}{c}\% \text { For Agree } \\
\text { The Statement }\end{array}$ \\
\hline 1 & I know what is Muamalat (transaction or dealings) & $28 \%$ \\
\hline 2 & $\begin{array}{l}\text { I know three prohibited elements in Muamalat are riba } \\
\text { (interest), Gharar (uncertainty) and Maysir (gambling) }\end{array}$ & $52 \%$ \\
\hline 3 & $\begin{array}{l}\text { I know riba is interest and it means an extra amount } \\
\text { the borrower need to pay from principal amount in } \\
\text { loan transaction. }\end{array}$ & $60 \%$ \\
\hline 4 & $\begin{array}{l}\text { I know gharar is uncertainty and it means uncertain } \\
\text { condition or situation in transaction. }\end{array}$ & $44 \%$ \\
\hline
\end{tabular}




\begin{tabular}{|c|c|c|}
\hline 5 & $\begin{array}{l}\text { I know maysir is gambling which easy acquisition } \\
\text { of wealth by chance, whether or not it deprives the } \\
\text { other's right. }\end{array}$ & $60 \%$ \\
\hline 6 & $\begin{array}{l}\text { I know that transaction committing with riba, gharar or } \\
\text { maysir will lead to illegal (haram) in Shariah. }\end{array}$ & $64 \%$ \\
\hline 7 & Multi level marketing (MLM) contains riba (interest). & $40 \%$ \\
\hline 8 & Insurance also contains riba (interest). & $16 \%$ \\
\hline 9 & $\begin{array}{l}\text { Patient get treatment in hospital may consist of gharar } \\
\text { fahish (major) }\end{array}$ & $24 \%$ \\
\hline 10 & $\begin{array}{l}\text { restaurant that not disclose price of the foods may } \\
\text { contains gharar fahish (major) }\end{array}$ & $24 \%$ \\
\hline 11 & Lucky draw contains maysir (gambling) & $40 \%$ \\
\hline 12 & Contest contains maysir (gambling) & $36 \%$ \\
\hline 13 & $\begin{array}{l}\text { I already know all these six activities contains } \\
\text { prohibited elements in Muamalat }\end{array}$ & $20 \%$ \\
\hline 14 & $\begin{array}{l}\text { I will avoid these activities that contains prohibited } \\
\text { elements even though it is common practice in our } \\
\text { daily life. }\end{array}$ & $\begin{array}{c}\text { YES }(92 \%) \\
\text { NO }(8 \%)\end{array}$ \\
\hline
\end{tabular}

The result found that most of the respondents know about muamalat, prohibited elements, and each of three prohibited elements in muamalat which are riba (interest), gharar (uncertainty) and maysir (gambling). However, there are lack of awareness of respondents regarding common activities in our daily life that contains prohibited elements. There are only $40 \%$ know that MLM contains riba, $16 \%$ know that insurance contains riba, $24 \%$ respondents know that patient get treatment in hospital without being disclose the price of consultation and medicine will contains gharar fahish (major) and restaurant for not disclose price of meal, and there are $40 \%$ and $36 \%$ know for lucky draw and contest may contains gambling in certain condition. Overall, only $20 \%$ of the respondents agree that they already know about these six activities contains prohibited elements in muamalat. It is only a small percentage of respondent who are aware of these six activities contains either riba, gharar and maysir, which could summarize that lack of awareness regarding these common activities practice in our daily life. 


\section{CONCLUSIONS}

The Islamic teachings need the Muslim to follow Allah's directives for earning a living, to use natural laws and direct means for the attainment of his objectives, and to employ such causes to produce the desired effects. Islam prohibits from practice riba, gharar and maysir in any transaction in our life. Therefore, as a Muslims, we need to avoid from any activities contains those prohibited elements.

Some activities contain these three elements indirectly which lead the Muslims did not realize that the concept is similar to the prohibited elements. However, these activities identified are activities that are commonly practice by Muslims. Research that has been done identified there are lack of awareness regarding common activities that contains prohibited elements in muamalat. However, $92 \%$ of the respondents agree that they will avoid these activities that contains prohibited elements even though it is common practice in our daily life. The rest $8 \%$ give reason that they did not agree with all the activities and they believe that those activities are unavoidable. In conclusion, people will aware and will try to avoid if they are know regarding its prohibition.

\section{ACKNOWLEDGEMENTS}

Thanks to my colleague, who is co-author of this paper, for valuable discussion and feedback, for endless support and effort in completing this paper. Thanks to the researcher who published their paper as my guidance in this paper. We also dedicated our appreciation to the respondents who were spent their time to give feedback to our survey. Last but not least, high appreciation to our family for always support and understanding during our research done. 


\section{REFERENCES}

Hanudin Amin, 2018. Unlocking Lucky Draw from an Islamic Perspective; The Borneo Post Sabah.

Investment and Finance Encyclopedia, 2013. Encyclopedia Database. Retrieved from https://www.investment-and-finance.net/islamicfinance/f/fiqh-muamalat.html

Mohammed Yusoff, 2013. Riba, Profit Rate, Islamic Rate, and Market Equilibrium International Journal of Economics, Management And Accounting.

Muhammad Iman, 2016. Contemporary Practice of Ribā, Gharar and Maysir In Islamic Banking and Finance. International Journal of Islamic Management and Business (Vol2-2).

Saifudin, 2017. Basic Principles of Muamalat. Fiqh: Kewangan Islam.

Saiful Azhar, 2015. Islamic Banking and Financial Market. Oxford Islamic Studies Online.

Shaykh Muhammad Saalih al Munajjid, 2004. Islam Question and Answer; Fatwa from the Standing Committee on the "Business and "Hibbat alJazeerah" companies and pyramid marketing schemes.

The Quran, 2019. Translated by Kamil et. al, Karya Bestari.

Uddin, 2015. Principles of Islamic Finance: Prohibition of Riba, Gharar and Maysir, Munich Personal RePEc Archive.

Zaharuddin Abd Rahman, 2017. Gharar \& Gambling In Daily Transactions. 
